J. AGROHITA, 3 (1) Oktober 2018 - Maret 2019 ISSN 2541-5956 (Print) ISSN 2615-336X (Online)
Universitas Muhammadiyah Tapanuli Selatan
Available online http://jurnal.um-tapsel.ac.id/index.php/agrohita

\title{
Peningkatan Produksi Tanaman Padi Sawah (Oryza Sativa L.) dengan Beberapa Jenis Mulsa dan Beberapa Varitas Pada Metode System of Rice Intensification (SRI)
}

\section{Increased Production of Rice Plants (Oryza Sativa L.) with Some Types of Mulch and Some Varieties on The Methods Of System of Rice Intensification (SRI)}

\author{
Amir Mahmud ${ }^{1 *}$, Mukhlis $^{1}$ \\ 1) Prodi Agroteknologi Fakultas Pertanian Universitas Muhammadiyah Tapanuli Seatan \\ Indonesia
}

*Email: amir.mahmud@um-tapsel.ac.id

\begin{abstract}
Abstrak
Penelitian ini telah di lakukan di Desa Purwodadi Kota Padangsidimpuan. Tujuan dari penelitian ini adalah untuk menguji peningkatan produksi tanaman padi sawah (Oryza sativa L.) pada metode System Of Rice Intensification. Percobaan ini menggunakan Rancangan Petak Terpisah (Split plot design) dalam pola RAK dengan dua faktor. Faktor utama adalah varietas padi sawah yang terdiri dari tiga taraf perlakuan yaitu varitas Aryze H6444, varitas Situ Bagendit dan varitas Siganteng. Faktor anak petak adalah penggunaan mulsa yang terdiri dari empat taraf perlakuan yaitu jerami padi, sekam padi, titonia dan mulsa plastik hitam. Varitas Siganteng dengan aplikasi mulsa plastik menunjukkan rataan panjang malai tertinggi dan terendah terdapat pada interaksi antara varitas Aryze H6444 Gold dengan aplikasi mulsa sekam padi. Varitas Siganteng dengan aplikasi mulsa jerami padi menunjukkan rataan jumlah gabah permalai tertinggi. Bobot gabah segar pertanaman tertinggi pada interaksi Varitas Siganteng dengan mulsa jerami padi tidak berbeda signifikan dengan interaksi varitas Siganteng dengan mulsa sekam padi. Bobot 1000 butir tertinggi terdapat pada interaksi antara varitas Siganteng dengan mulsa sekam padi. Bobot kering gabah per tanaman tertinggi pertanaman terdapat pada interaksi varitas Siganteng dengan mulsa plastik. Potensi produksi tertinggi terdapat pada interaksi varitas Siganteng dengan mulsa plastik yang menunjukkan rataan sebesar 16,85 ton/ha. Rataan terendah terdapat pada interaksi varitas Aryze H6444 Gold dengan mulsa titonia yang menunjukkan rataan sebesar 7,15 ton/ha.
\end{abstract}

Kata Kunci : jenis mulsa, varietas, metode SRI.

\section{Abstract}

The study was conducted in the village of Purwodadi, Padangsidimpuan City. The purpose of this study was to examine the increase in production of lowland rice (Oryza sativa L.) in the System Of Rice Intensification 
method. This experiment uses a Split plot design in a RAK pattern with two factors. The main factor is lowland rice variety consisting of three treatment levels, namely Aryze H6444 variety, Situ Bagendit variety, and Siganteng variety. The subplot factor is the use of mulch which consists of four treatment levels namely rice straw, rice husk, tithonia, and black plastic mulch. Siganteng variety with plastic mulch application showed the highest and lowest panicle lengths were found in the interaction between Aryze H6444 Gold variety and rice husk mulch application. Siganteng variety with mulch application of rice straw showed the highest average number of unprocessed rice. The highest planted fresh grain weight in Siganteng Variety interaction with rice straw mulch was not significantly different from the interaction of Siganteng variety with rice husk mulch. The highest 1000 grain weight was found in the interaction between Siganteng varieties and rice husk mulch. The highest dry weight of grain per plant was found in the interaction of Siganteng varieties with plastic mulch. The highest production potential is found in the interaction of Siganteng varieties with plastic mulch which shows an average of 16.85 tons/ha. The lowest average is found in the interaction of Aryze H6444 Gold variety with tithonia mulch which shows an average of 7.15 tons/ha.

Keywords: mulch, variety, system of rice intensification

\section{PENDAHULUAN}

Tanaman padi (Oryza sativa L.) merupakan tanaman penghasil beras yang menjadi makanan pokok bagi sebagian besar masyarakat Asia, dimana sekitar 92 persen kebutuhan beras dunia berada di Asia (Jahromi, Cother dan Ash, 2001; FAO, 2004). Total produksi beras nasional tahun 2015 sebesar 75,398 juta ton, dengan luas panen 14,117 ribu ha (BPS, 2016). Konsumsi beras nasional pada tahun 2016 adalah sekitar $114 \mathrm{~kg} / \mathrm{kapita} / \mathrm{tahun}$. Indonesia merupakan negara Asia yang memproduksi dan mengkonsumsi beras terbesar ke-tiga setelah Cina dan India (Mardianto dan Ariani, 2004).

Usaha ekstensifikasi pertanian padi sawah adalah dengan meningkatkan luas panen. Perkembangan luas panen sangat kecil, dari tahun 2014 sebesar 13.797 juta hektar dan pada tahun 2010-2011 sebesar 313.148 hektar meningkat 2,31 persen dan tahun 2015 sebesar 14.117 juta hektar meningkat 2,87 persen dan. Sementara itu produktivitas padi rerata nasional juga tergolong rendah yaitu berkisar pada 53,41 Ku/ha (BPS, 2016).

Peningkatan produksi padi di Indonesia perlu terus diusahakan, guna mencapai target produksi sesuai dengan kebutuhan.Diantara usaha untuk meningkatkan produksi padi adalah dengan menerapkan budidaya padi metode SRI (The System of Rice Intensification). Metode SRI merupakan metode penanaman padi sawah yang berbeda dengan padi biasa atau konvensional yang selama ini dilakukan oleh petani. 
Salah satu cara meningkatkan produksi pertanian adalah dengan cara memanipulasi lingkungan tumbuh tanaman. Upaya memanipulasi lingkungan yang dapat dilakukan yaitu dengan pemulsaan. Mulsa merupakan material yang dihamparkan di permukaan tanah. Pemberian mulsa dapat secara langsung berpengaruh terhadap lingkungan tumbuh tanaman seperti mencegah erosi, munculnya gulma, serta meningkatkan kadar air tanah, suhu tanah, udara tanah dan refleksi sinar matahari (Umboh, 2000).

Tujuan lain pemulsaan adalah untuk mengendalikan gulma. Menurut Sukman dan Yakup (2002) gulma perlu dikendalikan karena (1) menurunkan produksi akibat bersaing dalam pemanfaatan sarana tumbuh, (2) menurunkan mutu hasil akibat kontaminasi dengan bagian-bagian gulma, (3) mengeluarkan senyawa alelopati yang dapat menghambat pertumbuhan tanaman, (4) menjadi inang bagi hama dan patogen yang menyerang tanaman, meningkatkan biaya usaha tani akibat biaya penyiangan. Beberapa penelitian melaporkan bahwa biomassa tumbuhan seperti jerami padi serasah tumbuhan, termasuk alang-alang potensial digunakan sebagai mulsa (Fahrurrozi et. al., 2005; Sumarni et. al., 2006; Mayun 2007).

Penelitian mengenai penggunaan mulsa untuk tanaman padi belum banyak dilakukan. Oleh karena itu, perlu dilakukan penelitian tentang pengendalian gulma dengan beberapa jenis mulsa pada beberapa varietas tanaman Padi Sawah (Oryza sativa L) dengan metode System of Rice Intensification (SRI).

\section{METODE PENELITIAN}

Penelitian ini dilaksanakan pada lahan sawah yang terletak di Desa Purwodadi Kecamatan Batunadua Kota Padangsidimpuan dengan ketinggian tempat $\pm 350 \mathrm{~m} \mathrm{dpl,} \mathrm{waktu} \mathrm{percobaan} \mathrm{ini}$ dilaksanakan pada bulan Mei 2017 dan selesai pada bulan Agustus 2017.

Penelitian ini dilaksanakan dengan menggunakan Rancangan Petak Terpisah (Split plot design) dalam pola RAK dengan dua faktor. Faktor utama adalah varitas padi sawah yang terdiri dari tiga taraf perlakuan, dan faktor anak

P-ISSN 2541-5956, e-ISSN 2615-336X 
petak yaitu penggunaan mulsa yang terdiri dari empat taraf perlakuan.

Petak utama (main plot) : Beberapa varitas padi (V), terdiri dari 3 taraf :

$\mathrm{V}_{1}$ : Aryze H6444 Gold (hibrida)

$\mathrm{V}_{2}$ : Situ Bangendit (unggul)

$\mathrm{V}_{3}$ : Siganteng (lokal)

Anak petak (sub plot) : beberapa jenis mulsa (M), terdiri dari 4 taraf :

$\mathrm{M}_{1}$ : Mulsa jerami padi (6 ton/Ha)

$\mathrm{M}_{2}$ : Mulsa sekam padi (5 ton/Ha)

$\mathrm{M}_{3}$ : Mulsa Titonia (15 ton/Ha)

$\mathrm{M}_{4}$ : Mulsa Plastik

Dengan demikian terdapat 12 kombinasi perlakuan yang diulang sebanyak 3 kali ulangan, sehingga terdapat 36 unit percobaan. Model linier yang digunakan yaitu:

Yijk $=\mu+\rho_{\mathrm{k}}+\alpha_{\mathrm{i}}+\delta \mathrm{j}+(\alpha \delta)_{\mathrm{ij}}+\gamma \mathrm{ik}+\varepsilon \mathrm{ijk}$

Data hasil pengamatan disusun dalam anova untuk masing-masing peubah. Jika pengaruh perlakukan terhadap peubah diamati menunjukkan pengaruh yang nyata dapat dilanjutkan dengan uji beda rataan dengan uji DRMT pada taraf $5 \%$ (Gomez K.A, 1995).

Pengamatan terdiri dari, Panjang malai, Jumlah gabah per malai, Bobot gabah segar per malai, Bobot 1000 butir gabah bernas, Bobot kering gabah per tanaman, dan Potensi Produksi Per Hektar.

\section{HASIL DAN PEMBAHASAN}

\section{A. Panjang Malai (cm)}

Berdasarkan hasil Anova dapat diketahui bahwa perlakuan varietas, mulsa menunjukkan interaksi berbeda yang siginifikan. Rataan panjang malai dapat dilihat pada Tabel 1.

Hasil pada Tabel 1. menunjukkan bahwa ada interaksi antara varitas dengan aplikasi mulsa. Berdasarkan Tabel 1 dapat diketahui bahwa varitas Siganteng dengan aplikasi mulsa plastik menunjukkan rataan panjang malai tertinggi dengan rataan $31.56 \mathrm{~cm}$ dan varitas Siganteng dengan aplikasi jerami padi menunjukkan panjang malai yang hampir sama dengan aplikasi sekam padi dengan rataan $30.09 \mathrm{~cm}$ dan $30.13 \mathrm{~cm}$. Sedangkan perlakuan terendah terdapat pada interaksi antara varitas Aryze H6444 Gold dengan aplikasi mulsa sekam padi yang menunjukkan rataan sebesar $23.30 \mathrm{~cm}$.

P-ISSN 2541-5956, e-ISSN 2615-336X 
Jurnal Agrohita Volume 3 Nomor $1 \mid 6$

Tabel 1. Rataan Panjang Malai (cm)

\begin{tabular}{lcccc}
\hline \multirow{2}{*}{ Varietas } & \multicolumn{4}{c}{ Jenis Mulsa } \\
\cline { 2 - 5 } & Jerami Padi & Sekam Padi & Titonia & Plastik \\
\hline Aryze H6444 Gold & $24.74 \mathrm{a}$ & $23.30 \mathrm{c}$ & $23.86 \mathrm{~b}$ & $24.45 \mathrm{a}$ \\
\multirow{2}{*}{ Situ Bagendit } & $\mathrm{C}$ & $\mathrm{C}$ & $\mathrm{C}$ & $\mathrm{C}$ \\
\multirow{2}{*}{ Siganteng } & $26.81 \mathrm{ab}$ & $26.20 \mathrm{~b}$ & $27.20 \mathrm{a}$ & $26.51 \mathrm{~b}$ \\
& $\mathrm{~B}$ & $\mathrm{~B}$ & $\mathrm{~B}$ & $\mathrm{~B}$ \\
& $30.09 \mathrm{~b}$ & $30.13 \mathrm{~b}$ & $28.96 \mathrm{c}$ & $31.56 \mathrm{a}$ \\
\hline
\end{tabular}

Keterangan : Angka-angka dengan huruf kapital pada kolom yang sama dan huruf kecil pada baris yang sama menunjukkan perbedaan tidak signifikan menurut uji Duncan pada tingkat- $\alpha$ 5\%

Panjang malai yang secara statistik berbeda signifikan dapat disebabkan oleh perbedaan susunan genetik pada tanaman sehingga menghasilkan susunan genetik yang berbeda pada masing-masing jenis tanaman padi. Suhartatik, et al., (2010) menjelaskan bahwa varietas unggul memiliki daya hasil tinggi disebabkan oleh kemampuan genetik untuk beradaptasi dengan lingkungan.

Berdasarkan hasil penelitian ini bahwa varietas lokal memiliki panjang malai yang lebih panjang dibandingkan dengan panjang malai pada varietas hibrida dan varietas unggul. Hal ini dapat disebabkan oleh karena varitas lokal lebih mampu untuk beradaptasi terhadap keadaan lingkungan sehingga menghasilkan malai yang lebih panjang.

Pengamatan selanjutnya dilakukan pada jumlah gabah per malai diharapkan jumlah malai yang panjang akan menghasilkan jumlah gabah per malai yang lebih tinggi.

\section{Jumlah Gabah Permalai (Bulir)}

Berdasarkan hasil Anova dapat diketahui bahwa perlakuan varietas, mulsa menunjukkan interaksi berbeda yang siginifikan. Rataan jumlah gabah per malai dapat dilihat pada Tabel 2.

Tabel 2. Rataan Jumlah Gabah Per Malai (Bulir)

\begin{tabular}{lcccc}
\hline \multirow{2}{*}{ Varietas } & \multicolumn{4}{c}{ Jenis Mulsa } \\
\cline { 2 - 5 } & Jerami Padi & Sekam Padi & Titonia & Plastik \\
\hline Aryze H6444 Gold & $179.73 \mathrm{~b}$ & $175.13 \mathrm{~b}$ & $168.47 \mathrm{~b}$ & $192.27 \mathrm{a}$ \\
\multirow{2}{*}{ Situ Bagendit } & $\mathrm{B}$ & $\mathrm{B}$ & $\mathrm{B}$ & $\mathrm{B}$ \\
& $154.33 \mathrm{a}$ & $146.33 \mathrm{a}$ & $138.13 \mathrm{~b}$ & $143.80 \mathrm{a}$ \\
Siganteng & $\mathrm{C}$ & $\mathrm{C}$ & $\mathrm{C}$ & $\mathrm{C}$ \\
& $240.67 \mathrm{a}$ & $228.87 \mathrm{~b}$ & $209.33 \mathrm{c}$ & $205.73 \mathrm{c}$ \\
& $\mathrm{A}$ & $\mathrm{A}$ & $\mathrm{A}$ & $\mathrm{A}$ \\
\hline
\end{tabular}

Keterangan : Angka-angka dengan huruf kapital pada kolom yang sama dan huruf kecil pada baris yang sama menunjukkan perbedaan tidak signifikan menurut uji Duncan pada tingkat- $\alpha$ 5\%.

Hasil pada Tabel 2. menunjukkan ada interaksi antara varitas dengan apli-kasi mulsa. Namun, berdasarkan Tabel 2 dapat diketahui bahwa varitas Siganteng dengan 
aplikasi mulsa jerami padi me-nunjukkan rataan jumlah gabah permalai tertinggi dengan rataan sebesar 240.67 bulir sedangkan terendah terdapat pada perlakuan interaksi antara varitas Situ Bagendit dengan aplikasi mulsa Titonia yang menunjukkan rataan sebesar 138.13 bulir. Hal ini memperlihatkan bahwa perbedaan varietas dapat mempe-ngaruhi jumlah gabah permalai. Jumlah gabah per malai yang semakin tinggi akan dapat meningkatkan produksi tanaman padi.

Berdasarkan jenis varietas bahwa pada penelitian ini Varietas Siganteng yang merupakan varietas lokal merupakan varietas yang memiliki jumlah ga-bah tertinggi jika dibandingkan dengan varietas hibrida (Aryze H6444 Gold) dan varietas unggul (Situ Bangendi). Hal ini erat kaitannya dengan adaptabilitas dan stabilitas dari varietas hibrida dan varietas unggul yang lebih rendah dibandingkan dengan varietas lokal. Septrina, (2008) menjelaskan bahwa adaptabilitas dan stabilitas suatu varietas dapat mempengaruhi hasil gabah. Selanjutnya Siregar et al., (1998) menyatakan bahwa semakin tinggi jumlah gabah maka cenderung akan meningkatkan hasil panen.

\section{Bobot Gabah Segar Permalai (g)}

Berdasarkan hasil Anova dapat diketahui bahwa perlakuan varietas, mulsa menunjukkan interaksi berbeda yang siginifikan. Rataan bobot gabah per tanaman dapat dilihat pada Tabel 3.

Tabel 3. Rataan Bobot Gabah Segar Per Malai (g)

\begin{tabular}{lcccc}
\hline \multirow{2}{*}{ Varietas } & \multicolumn{4}{c}{ Jenis Mulsa } \\
\cline { 2 - 5 } & Jerami Padi & Sekam Padi & Titonia & Plastik \\
\hline Aryze H6444 Gold & $3.60 \mathrm{~b}$ & $3.50 \mathrm{~b}$ & $3.37 \mathrm{c}$ & $3.85 \mathrm{a}$ \\
\multirow{2}{*}{ Situ Bangendit } & $\mathrm{B}$ & $\mathrm{B}$ & $\mathrm{B}$ & $\mathrm{B}$ \\
& $3.09 \mathrm{a}$ & $2.93 \mathrm{ab}$ & $2.76 \mathrm{~b}$ & $2.87 \mathrm{~b}$ \\
Siganteng & $\mathrm{C}$ & $\mathrm{C}$ & $\mathrm{C}$ & $\mathrm{C}$ \\
& $4.81 \mathrm{a}$ & $4.58 \mathrm{~b}$ & $4.19 \mathrm{c}$ & $4.11 \mathrm{c}$ \\
& $\mathrm{A}$ & $\mathrm{A}$ & $\mathrm{A}$ & $\mathrm{A}$ \\
\hline
\end{tabular}

Keterangan: Angka-angka dengan huruf kapital pada kolom yang sama dan huruf kecil pada baris yang sama menunjukkan perbedaan tidak signifikan menurut uji Duncan pada tingkat- $\alpha 5 \%$.

Hasil pada Tabel 3. menunjukkan bahwa bobot gabah segar pertanaman tertinggi terdapat pada interaksi Varitas Siganteng dengan mulsa jerami padi yaitu dengan nilai 3 tidak berbeda signi-fikan dengan interaksi varitas Siganteng dengan mulsa sekam padi yang menun-jukkan nilai 4.58 .
Sedangkan bobot gabah segar pertanaman terendah terdapat pada interaksi varitas Situbagendit dengan mulsa Titonia dengan nilai 2.76, tidak berbeda signifikan dengan interaksi varitas Situ Bagendit dengan mulsa plas-tik dan sekam padi. Sehubungan dengan itu, berdasarkan hasil percobaan menun- 
Jurnal Agrohita Volume 3 Nomor $1 \mid 8$

jukkan bahwa perlakuan interaksi padi yang dapat menurunkan suhu menunjunjukkan perbedaan yang signi- sedangkan sifat dari mulsa dapat fikan. meningkatkan suhu tanah. Hal ini

Bobot gabah segar pertanaman tertinggi adalah pada interaksi antara Varietas Siganteng dengan mulsa sekam padi, hal ini dapat sebabkan oleh kandungan bahan organik pada mulsa sekam padi sehingga meningkatkan jumlah hara di dalam tanah. Purwowidodo, (1983) menjelaskan bahwa pemanfaatan bahan organik sebagai mulsa selain dapat mengurangi efek negatif dari gulma juga dapat mening-katkan kandungan bahan organik tanah. Pengamatan selanjutnya dilakukan pada bobot kering pertanaman.

Penggunaan mulsa jerami padi yang lebih baik dibandingkan dengan mulsa plastik dapat disebabkan oleh sifat jerami dijelaskan oleh Fadriansyah, (2015) yang menyatakan bahwa Mulsa jerami memiliki sifat menurunkan suhu dan tidak menyerap seluruh radiasi yang diterima, sedangkan sifat dari warna hitam pada mulsa plastik cenderung mening-katkan suhu tanah, karena radiasi yang diterima sebagian besar diserap.

\section{Bobot 1000 Butir (g)}

Berdasarkan hasil Anova dapat diketahui bahwa perlakuan varietas menunjukkan interaksi berbeda yang siginifikan, sedangkan perlakuan mulsa belum menunjukkan perbedaan yang signifikan. Rataan bobot 1000 butir dapat dilihat pada Tabel 4 .

Tabel 4. Rataan Bobot 1000 Butir (g)

\begin{tabular}{lcccc}
\hline \multirow{2}{*}{ Varietas } & \multicolumn{4}{c}{ Jenis Mulsa } \\
\cline { 2 - 5 } & Jerami Padi & Sekam Padi & Titonia & Plastik \\
\hline Aryze H6444 Gold & $27.54 \mathrm{a}$ & $24.29 \mathrm{~b}$ & $23.80 \mathrm{c}$ & $23.47 \mathrm{c}$ \\
Situ Bangendit & $\mathrm{B}$ & $\mathrm{C}$ & $\mathrm{B}$ & $\mathrm{B}$ \\
& $29.73 \mathrm{~b}$ & $29.50 \mathrm{c}$ & $30.90 \mathrm{a}$ & $27.73 \mathrm{c}$ \\
Siganteng & $\mathrm{A}$ & $\mathrm{B}$ & $\mathrm{A}$ & $\mathrm{A}$ \\
& $23.68 \mathrm{~d}$ & $32.12 \mathrm{a}$ & $30.53 \mathrm{~b}$ & $27.86 \mathrm{c}$ \\
& $\mathrm{C}$ & $\mathrm{A}$ & $\mathrm{A}$ & $\mathrm{A}$
\end{tabular}

Keterangan : Angka-angka dengan huruf kapital pada kolom yang sama dan huruf kecil pada baris yang sama menunjukkan perbedaan tidak signifikan menurut uji Duncan pada tingkat- $\alpha$ 5\%.

Hasil pada Tabel 4. menunjukkan bahwa bobot 1000 butir tertinggi terdapat pada interaksi antara varitas Siganteng dengan mulsa sekam padi yang menunjukkan rataan bobot 1000 butir sebesar 32.12 sedangkan interaksi dengan bobot 1000 butir terendah terdapat pada interaksi antara varitas Aryze H6444 Gold dengan mulsa plastik yang menunjukkan rataan bobot 1000 butir sebesar 23.47. Hal ini terkait dengan kemampuan mulsa 
sekam padi dalam menyediakan unsur hara bagi tanaman.

Mulsa sekam padi yang telah diaplikasikan pada tanah lama kelamaan akan terdekomposisi sehingga dapat menambah unsur hara pada tanaman. Jika unsur hara pada tanah meningkat maka akan meningkatkan jumlah biomassa pada tanaman. Jannah, et al., (2011) menjelaskan bahwa bobot 1000 butir gabah isi menyatakan banyaknya biomassa yang terkandung dalam gabah. Semakin bernas gabah menandakan biomassa yang terkandung di dalamnya semakin banyak. Kebernasan gabah sangat ditentukan oleh terjaminnya ketersediaan hara dan terjaminnya proses fisiologi tanaman. Semakin banyak gabah yang terbentuk semakin tinggi beban tanaman untuk membentuk gabah yang berisi (bernas).
Selanjutnya Hakim, et al., (1986) menjelaskan bahwa tersedianya unsur hara dalam jumlah yang cukup dan seimbang menyebabkan proses metabo-lisme tanaman berjalan lancar sehingga pembentukan protein, karbohidrat dan pati tidak terhambat.

\section{Bobot Kering Gabah Per Tanaman (g)}

Berdasarkan hasil Anova dapat diketahui bahwa perlakuan pemberian mulsa menunjukkan interaksi berbeda yang siginifikan, sedangkan perlakuan varietas belum menunjukkan perbedaan yang signifikan. Rataan bobot kering gabah per tanaman dapat dilihat pada Tabel 5.

Tabel 5. Rataan Bobot Kering Gabah Per Tanaman (g)

\begin{tabular}{lcccc}
\hline \multirow{2}{*}{ Varietas } & \multicolumn{4}{c}{ Jenis Mulsa } \\
\cline { 2 - 5 } & Jerami Padi & Sekam Padi & Titonia & Plastik \\
\hline Aryze H6444 Gold & $126.52 \mathrm{a}$ & $106.73 \mathrm{~b}$ & $64.39 \mathrm{c}$ & $127.38 \mathrm{a}$ \\
\multirow{2}{*}{ Situ Bagendit } & $\mathrm{A}$ & $\mathrm{A}$ & $\mathrm{C}$ & $\mathrm{B}$ \\
& $117.92 \mathrm{a}$ & $90.63 \mathrm{~b}$ & $93.39 \mathrm{~b}$ & $113.64 \mathrm{a}$ \\
Siganteng & $\mathrm{B}$ & $\mathrm{B}$ & $\mathrm{B}$ & $\mathrm{C}$ \\
& $120.07 \mathrm{~b}$ & $91.85 \mathrm{~d}$ & $106.42 \mathrm{c}$ & $151.61 \mathrm{a}$ \\
Keterangan : & $\mathrm{A}$ & $\mathrm{B}$ & $\mathrm{A}$ & $\mathrm{A}$ \\
\hline & Angka-angka dengan huruf kapital pada kolom yang sama dan huruf kecil pada baris yang \\
& Sama menunjukkan perbedaan tidak signifikan menurut uji Duncan pada tingkat- $\alpha$ 5 $\%$
\end{tabular}

Hasil pada Tabel 5. menjelaskan bahwa bobot kering gabah per tanaman tertinggi pertanaman terdapat pada interaksi varitas Siganteng dengan mulsa plastik dengan nilai sebesar 151.61 yang berbeda signifikan dengan seluruh perlakuan, sedangkan rataan bobot kering gabah per tanaman terendah terdapat pada interaksi varitas Aryze H6444 Gold dengan titonia yang dengan nilai sebesar 64.39 juga berbeda signifikan dengan perlakuan lainnya. 
Penggunaan mulsa jerami padi, sekam padi dan Titonia akan mengalami dekomposisi sedangkan mulsa plastik tidak mengalami dekomposisi. Terjadinya proses dekomposisi pada mulsa organik menyebabkan intensitas cahaya matahari lebih besar kepermukaan tanah sehingga menyebabkan pertumbuhan gulma semakin cepat.

Menurut Purwowidodo (1988) salah satu kegunaan mulsa dapat menghalangi intensitas cahaya kepermu-kaan tanah. Hal ini menyebabkan biji gulma yang berkecambah kurang mam-pu melanjutkan proses fotosintesa untuk pertumbuhannya.

\section{Potensi Produksi Tanaman Per Hektar (ton/ha)}

Berdasarkan hasil Anova dapat diketahui bahwa perlakuan mulsa menunjukkan interaksi berbeda yang siginifikan, sedangkan perlakuan varietas belum menunjukkan perbedaan yang signifikan. Rataan potensi produksi tanaman perhektar dapat dilihat pada Tabel 6.

Tabel 6. Potensi Produksi Tanaman Per Hektar (ton/ha)

\begin{tabular}{lcccc}
\hline \multirow{2}{*}{ Varietas } & \multicolumn{4}{c}{ Jenis Mulsa } \\
\cline { 2 - 5 } & Jerami Padi & Sekam Padi & Titonia & Plastik \\
\hline Aryze H6444 Gold & $14.06 \mathrm{a}$ & $11.86 \mathrm{~b}$ & $7.15 \mathrm{c}$ & $14.16 \mathrm{a}$ \\
\multirow{3}{*}{ Situ Bagendit } & $\mathrm{A}$ & $\mathrm{A}$ & $\mathrm{C}$ & $\mathrm{B}$ \\
& $13.10 \mathrm{a}$ & $10.07 \mathrm{~b}$ & $10.38 \mathrm{~b}$ & $12.62 \mathrm{a}$ \\
Siganteng & $\mathrm{B}$ & $\mathrm{B}$ & $\mathrm{B}$ & $\mathrm{C}$ \\
& $13.34 \mathrm{~b}$ & $10.20 \mathrm{~d}$ & $11.82 \mathrm{c}$ & $16.85 \mathrm{a}$ \\
& $\mathrm{A}$ & $\mathrm{B}$ & $\mathrm{A}$ & $\mathrm{A}$ \\
\hline
\end{tabular}

Keterangan : Angka-angka dengan huruf kapital pada kolom yang sama dan huruf kecil pada baris yang sama menunjukkan perbedaan tidak signifikan menurut uji Duncan pada tingkat- $\alpha 5 \%$.

Hasil pada Tabel 6. dapat diketahui bahwa rataan potensi produksi tertinggi terdapat pada interaksi varitas Siganteng dengan mulsa plastik yang menunjukkan rataan sebesar 16.85 ton/ha selanjutnya interaksi varitas Aryze H6444 Gold dengan mulsa plastik dengan rataan sebesar 14.16 ton/ha. Rataan terendah terdapat pada interaksi varitas Aryze H6444 Gold dengan mulsa titonia yang menunjukkan rataan sebesar 7.15 ton/ha.

Penggunaan mulsa jerami padi pada varitas Siganteng dan mulsa sekam padi pada varitas Aryze H6444 Gold menunjukkan hasil yang tidak jauh berbeda. Interaksi antara varitas Siganteng dengan mulsa sekam padi menunjukkan potensi produksi sebesar 13.34 ton/ha, varitas Aryze H6444 Gold dengan menggunakan mulsa sekam padi menunjukkan potensi produksi sebesar 11.86 ton/ha. Walaupun hasil tersebut lebih rendah dibandingkan dengan penggunaan plastik. Namun, hal ini telah membuktikan bahwa ada pengaruh penggunaan mulsa terhadap potensi 
produksi padi. Hakim, et al., (1986) menjelaskan bahwa penambahan organik sekam padi akan memperbaiki kondisi tanah untuk penetrasi akar, infiltrasi air dan aerasi. Selanjutnya Purwowidodo (1983) menjelaskan bahwa pemanfaatan bahan organik sebagai mulsa selain dapat mengurangi efek negatif dari gulma juga dapat meningkatkan kandungan bahan organik tanah.

\section{KESIMPULAN}

Varitas Aryze H6444 Gold dan varitas Siganteng menunjukkan hasil terbaik pada penggunaan mulsa plastik, sedangkan varitas Situ Bagendit menunjukkan hasil terbaik pada mulsa jerami padi.

\section{Jenis gulma Ludwigia octovalvis} merupakan gulma yang mendominasi pada pemberian mulsa jerami padi, sekam padi dan mulsa plastik. Sedangkan pada mulsa Titonia jenis gulma yang mendominasi adalah gulma Eleusine indica.

Penggunaan mulsa plastik lebih baik dari pada penggunaan mulsa Titonia, mulsa jerami padi dan sekam padi dalam menekan pertumbuhan gulma pada tanaman padi sawah dengan sistem SRI.

Potensi produksi terbaik diperoleh dari aplikasi mulsa plastik pada varitas Siganteng sebanyak 16.85 ton per Ha

\section{DAFTAR PUSTAKA}

Abdullah, B. 2008. Perkembangan dan proses perakitanpadi tipe baru di Indonesia. Jurnal Litbang Pertanian27(1).

Abdullah, B. 2009. Progress of rice through recurrentselection. J. Agron. Indonesia 37 (3): 188-193.

Adisarwanto, T dan Rini W. 2002. Meningkatkan Hasil Panen Kedelai. Penebar Swadaya. Jakarta. 86 hal.

Anderson, W. P. 1977. Weed Sciences: Principles. West Publishing Company 598 p.

BPS, 2016. Produksi, Luas Panen dan Produktivitas Padi di Indonesia, 2011 - 2015. Jakarta. Indonesia

Buhaira. 2010. Pertumbuhan dan Hasil Padi (Oryza sativa) yang Dibudidayakan secara SRI Organik pada Beberapa Cara dan Waktu Penyiangan Gulma. ISSN 0854-8986 : 110.

Chung, I.M, K.H. Kim, J.K. Ahn, S.B. Lee, S.H. Kim, dan S.J. Hahn. 2003. "Comparison of allelopathic potential of rice leaves, straw, and hull extract on barnygrass". Agron. J. 95: 1063-1070.

De Datta, S. K. 1981. Principles dan Practices of Rice Production. Toronto. John Wiley \& Sons.618 p.

Decentralized Irrigation System Improvement Project in Eastren Region of Indonesia (DISIMP). 2005. "SRI The System of Rice Intensification in East Indonesia". Nippon Koei.JBIC.

Departemen Pertanaian. 2007. Uji lapang alsintan mendukung budidaya tanaman padi sawah secara terpadu. www.mekanisasi.litbang.deptan.go.id. Diakses 14 Januari 2007.

Fadriansyah, A. 2015. Pengaruh Takaran Mulsa Jerami Padi Terhadap Pertumbuhan dan Hasil Tanaman Kedelai (Glycine max L.). Skripsi Fakultas Pertanian Universitas Tamansiswa Padang. Padang.

Fahrurrozi, B. Hermawan, dan Latifah. 2005. Pertumbuhan Dan Hasil Kedelai PadaBerbagai Dosis Mulsa Alang-Alang Dan Penolahan Tanah. Jurnal AktaAgrosia 8(1):21-24

FAO. 2004. "Rice and water: a long and diversified story". FAO United Nation. Rome. Italy.

Fitri, H. 2009. Uji Adaptasi Beberapa Varietas Padi Ladang (Oryza sativa L.). Skripsi. Fakultas Pertanian Universitas Sumatera Utara.

Gao, S., K.K. Tanji dan S.C. Scardaci. 2004. "Impact of rice straw incorporation on soil redox status and sulfide toxicity". Agron. J. 96: 70-76.

P-ISSN 2541-5956, e-ISSN 2615-336X 
Gardner, P. F.,R. B. Pearce dan R. L. Mitchell. 1991. Fisiologi Tanaman Budidaya Diterjemahkan oleh H. Susilo. Universitas Indonesia Press. Jakarta

Gomez, K. A. dan A. A. Gomez. 1995. Prosedur Statistik untuk Penelitian Pertanian. (Terjemahan). E. Syamsudin dan J. S. Baharsjah. UI Press. Jakarta. 698 hal

Grist D.H., 1960. Rice. Formerly Agricultural Economist, Colonial Agricultural Service, Malaya. Longmans, Green and Co Ltd. London.

Grist, D. H. 1965. Rice. $4^{\text {th }}$ edition. Longman Group Limited. London. 548 p.

Hakim, N., Y. Nyakpa, A.M. Lubis, S.G. Nugroho, M.R. Saul, M.A. Diha, G.B. Hong \& H.H. Bailey. 1986. Dasar-dasar ilmu tanah (TNH). Bandar Lampung: Penerbit Universitas Lampung.

Hanum, C. 2008. Teknik Budidaya Tanaman. Jakarta : Departemen Pendidikan Nasional.

Hasanah, I. 2007. Bercocok Tanam Padi. Azka Mulia Media. Jakarta. 68 hal.

Herawati, W. D. 2012. Budidaya Padi. Javalitera. Jogjakarta. 100 hal.

Holmes, J. R., 1977, Chemical Reactor Design for Process Plant, Volume One : Principles and Techniques, John Wiley and Sons, Inc., New York

IRRI. 1985. Gulma. PT Bhratara Karya Aksara. Jakarta. 120 hal

Jahromi, , F., E Cother, dan G. Ash. 2001. "Weed control in rice crops - Sustainability of Rhyncosporium alismatis as a Mycoherbicide for integrated Management of Damasonium minus in Rice Fields". Australia. RIRDC Publication No. 01/39.

Jannah, A. Yayu, S.R. dan Kuswarini.Respon Pertumbuhan dan Produksi Padi (Oryza sativa L.) Varietas Ciherang pada Pemberian Kombinasi Dosis Pupuk Anorganik dan Pupuk Kandang Ayam. Jurnal Unsika. Hlm.1-15.

Jatmiko, S.Y., Harsanti S., Sarwoto, dan A.N. Ardiwinata. 2002. Apakah herbisida yang digunakan cukup aman? hlm. 337-348. Dalam J. Soejitno, I.J. Sasa, dan Hermanto (Ed.). Prosiding Seminar Nasional Membangun Sistem Produksi Tanaman Pangan Berwawasan Lingkungan. Pusat Penelitian dan Pengembangan Tanaman Pangan, Bogor.

Lee, L. J. dan Ngim J. 2000. Control of Asystasia intrusa (BI) In Pineapple with Emphasis on New Techniques. Papper presented at the Seminar and Discussion on the Weed Asystasia, West Johore Agric. Dev. Project, Pontian, 16 pp.
Lin, XQ, D.F. Zhu, H.Z. Chen, dan Y.P. Zhang. 2009. Effects of plant density and nitrogen application rate on grain yield and nitrogen uptake of super hybrid rice. Rice Science 16(2):138-142.

Manurung, S.O. dan M. Ismunadji. 1988. Morfologi dan Fisiologi Padi, hal 55- 102 dalam Manurung, Ismunadji, Roechan, dan Suwardjo (penyunting). Padi Buku 1. Pusat Penelitian dan Pengembangan Tanaman Padi. Badan Penelitian dan Pengembangan Pertanian, Bogor.

Mardianto, S dan M. Ariani. 2004. "Kebijakan proteksi dan promosi komodisti beras di Asia dan prospek pengembangannya di Indonesia". AKP. Vol. 2 (4): 340-353.

Mayun, I. D. 2007. Efek Mulsa Jerami Padi Dan Pupuk Kandang Sapi TerhadapPertumbuhan Dan Hasil Bawang Merah Di Daerah Pesisir. Agritrop, 26 (1) :33-40

Medan Bisnis.2014, Padi Siganteng Bakal Jadi Varietas Unggul Madina.Selasa, 09 Sep $2014 \quad$ 08:37 WIB http://mdn.biz.id/n/116411/.

Mercado, B. L. 1979. Introduction to Weed Science. Southeast Asia Regional Centre for Graduate Study and Research in Agriculture. p 37-69.

Moenandir, J. 1988. Fisiologi Herbisida (Ilmu Gulma: Buku II). Rajawali Pers. Jakarta. 143 hal

National Academy of Sciences. 1969. Weed Control. National Academy of Sciences. Washington D. C. 471 p.

Pitoyo, J. 2006. Mesin Penyiang Gulma Padi Sawah Bermotor. Sinar Tani.Edisi 5-11 Juli 2006. http://www.pustakadeptan.go.id

Prawiranata,W.E., S.Heru dan P. Tjadronogoro. 1981. Dasar-Dasar Fisiologi Tumbuhan. Jilid II. IPB. Bogor.

Purwowidodo. 1983. Teknologi Mulsa. Dewaruci. Jakarta.

Purwowidodo. 1988. Teknologi Mulsa. Dewa Ruci Press. Jakarta.

Rachman, A., Z. Lamid, G. Adlis dan Syafruddin. 1994. "Perubahan komposisi gulma pada lahan bekas alang-alang". Prosiding Konferensi HIGI XII; p. 31-36.

Renan Subantoro, et al., 2008. Pemuliaan Tanaman Padi (Oryza sativa L.) VARIETAS Lokal Menjadi Varietas Lokal Yang Unggul. Mediagro.Vol 4. No 2, 2008: HAL 62 -74

Rusman B. 1985. Pengaruh Pemberian Sisa Tanaman Sebagai Mulsa Terhadap Sifat Fisik Tanah Dan Produksi Tanaman Jagung Pada Tanah Podsolik. Laporan Penelitian. 23 hal. 
Sastroutomo, S. 1999. Ekologi Gulma. Gramedia Pustaka Utama. Jakarta. 207 hal.

Septrina G. 2008. Pengaruh Waktu dan Cara Pengendalian Gulma terhadap Pertumbuhan dan Hasil Padi Hibrida.[Skripsi]. Bogor (ID): Institut Pertanian Bogor.

Setjen Deptan. 2007. Undang-undang No. 26 Tahun 2007 tentang Penataan Ruang. Lembaran Negara RI Tahun 2007 Sekretariat Negara. Jakarta. http://pusdatin.setjen.deptan.go.id/.

Diakses pada April 2017 pukul 15.00 WIB.

Siregar, H., Endang, Suparman dan Soewito.1998. Analisis Beberapa Sifat Galur Padi Sawa Dua Musim Tanam. J stabilitas padi sawah $16(2)$ : $18-19$.

Sitompul, S dan Guritno, B. 1995.Analisis Pertumbuhan Tanaman.Gadjah Mada University Press.Yogyakarta.

Smith, R. J. 1983. Weeds of major economic importan ce in rice and yield losses due to weed competition. p 19-35. In: Weed Control in Rice. International Rice Research Institute. Los Banos. 264 p.

Suharno.(2005). Perlindungan Tanaman. Diktat STPP, jurluhtan, Yogyakarta

Suhartatik, E dan Makarim, Ak. 2010. Morfologi dan Fisiologi Tanaman Padi. Balai Besar Penelitian Tanaman Padi. Bogor.

Suhartatik. 2008. Morfologi dan Fisiologi Tanaman Padi.

http://www.google.com/url.litbang.deptan .go.id\%spesial\%padi2009. Diakses 28 Maret 2017.

Sujatna, U. 2010. Pola Tanam SRI. Ganesha Entrepreneur

Club. http://www.infoorganik.com

Sukman, Y. dan Yakup. 2002. Gulma Dan Teknik Pengendaliannya. PT Raja Grafindo Persada. Jakarta. 159 hal.

Sumarni, N., A. Hidayat, dan E. Sumiati. 2006. Pengaruh Tanaman Penutup TanahDan Mulsa Organik Terhadap Produksi Cabai Dan Erosi Tanah. J. Hort.16(3):197-201.

Suparyono dan Setyono. A. 1997. Mengatasi Permasalahan Budidaya Padi. Penebar Swadaya. Jakarta.

Suparyono, Suprihanto, dan Sudir., 2001. Pemanfaatan Benih Sehat dan Mikroorganisme Terbawa Benih Sebagai Komponen Utama PHT Beberapa Penyakit Penting Tanaman Padi.Laporan hasil penelitian Balitpa, 2001.

Supriyadi, A. 2001. Uji Efikasi Herbisida Metsulfuron Metil untuk Pengendalian Gulma di Perkebunan Karet. Jurnal Jurusan Budidaya FP UMY IX (2) : 64 68.
Suyana dan U.H. Prajogo. 1997.Subsidi Benih dan Dampaknya Tehadap Peningkatan Produksi Pangan. Kebijakan Pembangunan Pertanian. Analisis Kebijaksanaan Antisipatif dan Re-sponsif. Pusat Penelitian Sosial ekonomi Pertanian. Badan Litbang Pertanian

Umboh H A. 2000. Petunjuk Penggunaan Mulsa. Penebar Swadaya. Jakarta. 98 hal.

Uphoff, N. dan Kassam, A. 2009.“Agricultural technolgies for developing countries. Case study The System of Rice Intensification". Rome. Italy: FAO UN.

Willcox, V. D. 2012. Weed Survey-Southern States Grass Subsection. Proc South Weed Sci. Soc. 57 (3): 420-423.

Zulmardi. 2016. Pengenalian Gulma pada Padi Sawah dengan Pemberian Bahan Organik pada Metode Sri (System of Intensification). Tesis. Program Pascasarjana. Universitas Andalas. Padang. 